\title{
Growth, Productivity, and Mineral Composition of Hydroponically Cultivated Greenhouse Tomatoes, with or without Nutrient Solution Recycling
}

\author{
H. Zekki ${ }^{1}$, L. Gauthier ${ }^{2}$, and A. Gosselin ${ }^{3}$ \\ Département de l'Envirotron, Centre de Recherche en Horticulture, Université Laval, Québec, \\ Canada, G1K $7 P 4$
}

Additional index words. artificial substrates, mineral absorption, drainage recycling, Lycopersicon esculentum

\begin{abstract}
Tomato plants (Lycopersicon esculentum Mill. cv. Capello) were grown in the three most promising and used hydroponic cultivation systems using rockwool and peatmoss substrates and nutrient film technique (NFT), either with or without recovery and recycling of the drainage solutions. Prolonged recycling of nutrient solutions in NFT caused a reduction in fresh weight, dry weight, and yield compared to plants grown in NFT with regular renewal of the nutrient solution. There were no differences in growth, productivity, and leaf mineral composition between plants grown in rockwool and peatmoss systems, with or without recycling, and in the NFT system without recycling. These results suggest that recycling drainage solutions is an economically and environmentally sound horticultural practice that when used correctly does not cause a reduction in yield of tomatoes cultivated in rockwool or peatmoss. However, prolonged use of the same solution in the NFT cultivation system can negatively affect growth and yield. This is most likely due to an accumulation of sulfate ions in the fertigation solutions.
\end{abstract}

Hydroponic cultivation, a current practice all over the world, is a method that permits good control of plant growth and development. However, maintaining optimal conditions for growth and development requires proper climate management and the use of well-balanced irrigation solutions that meet the mineral requirements of specific crops and cultivars. To avoid the build-up of toxins, mineral deficiencies, nutrition abnormalities, or the spread of disease, producers using the nutrient film technique (NFT) systems periodically empty the solution basins or let them drain when cleaning or flushing the system. However, collecting and recycling hydroponic nutrient solutions is an alternative that has become more appealing to producers and researchers (De Hoog, 1990). In Europe, new legislation drafted to reduce the environmental impact of horticulture is forcing greenhouse growers to invest in closed fertigation systems (Baars, 1992).

In recent studies, improved fertigation management was considered the best practice for recycling waste solutions from greenhouse production. In fact, adding water and fertilizer to recycled drainage solutions based on changing climatic conditions may contribute to reductions in fertilizer use and, hence, reductions in $\mathrm{NO}_{3}$ concentration of the soils and aquifers (Mankin and Fynn, 1992).

The adjustment of nutrient solutions in closed systems can result in an accumulation of some minerals. This accumulation most often occurs with sulfates that are continuously added to the nutrient solution as a component of certain fertilizers (e.g., $\mathrm{K}_{2} \mathrm{SO}_{4}$, $\mathrm{MgSO}_{4}$ ) and not absorbed at the same rate as the elements with

Received for publication 9 Mar. 1995. Accepted for publication 4 Apr. 1996. Paper no. CRH-142. We thank R. Pouliot, J. Charbonneau, S. Roy, F. Labbé, and A. Menard for technical support. We also thank the Conseil de Recherche en Pêche et Agro-alimentaire du Québec for its continuing financial support of this project. The cost of publishing this paper was defrayed in part by the payment of page charges. Under postal regulations, this paper therefore must be hereby marked advertisement solely to indicate this fact.

${ }^{1}$ Graduate research assistant. Current address: Pavillon. of Envirotron, Université Laval, Québec, Canada, G1K 7P4.

${ }^{2}$ Professor, Département de génie rural.

${ }^{3}$ Professor and department head, Département de phytologie. which they are co-transported (Boivin, 1990). Due to the number of adjustments made in the recycling process, this accumulation can become important. Besides sulfates, chlorides and bicarbonates also have a tendency to accumulate, and can influence crop growth (Baars, 1992). Cerdra et al. (1984) and Martinez et al. (1983) reported that high sulfate concentrations negatively affect growth and development of tomato plant leaves and stems. Our objective was to examine the effect of recycling nutrient solution on yield, mineral nutrition, and nutrient solution composition using tomato as a test crop.

\section{Materials and Methods}

Capello tomato seeds were sown on 17 Feb. 1993 in rockwool cubes (Grodan AM 38/40; Grodan, Grodania, Denmark; $38 \times 36 \times$ $40 \mathrm{~mm}$ ) and transplanted 1 week later into rockwool blocks (DM 4S; Grodan; $75 \times 75 \times 65 \mathrm{~mm})$. Plants were fertilized with a complete nutrient solution (in $\left.\mathrm{mg} \cdot \mathrm{L}^{-1}\right)(148 \mathrm{~N}, 36 \mathrm{P}, 168 \mathrm{~K}, 120 \mathrm{Ca}$, $28 \mathrm{Mg}, 0.75 \mathrm{Fe}, 0.64 \mathrm{Mn}, 0.22 \mathrm{Zn}, 0.03 \mathrm{Cu}, 0.2 \mathrm{~B}$, and $0.07 \mathrm{Mo}$ ) after the first leaf appeared (Conseil des Productions Végétales du Québec, 1990). Natural light was supplemented by high-pressure sodium lamps (HPS) at a photosynthetic photon flux (PPF) of 150 $\mu \mathrm{mol} \cdot \mathrm{m}^{-2} \cdot \mathrm{s}^{-1}$ during a $16-\mathrm{h}$ photoperiod.

On 8 Apr. 1993, at the four- to five-leaf stage, transplants were placed in three different hydroponic systems: NFT (Cooper, 1979), rockwool (Grodan), and peatmoss (ALLEGRO, Premier Peatmoss, Rivière-du-Loup, Canada) in four glasshouses at Laval Univ. Planting density was 4 plants $/ \mathrm{m}^{2}$. Each greenhouse was divided into six sections with six treatments (three with and three without nutrient solution recycling) for each cultivation system.

The NFT systems were made of plastic troughs $(2.3 \mathrm{~m}$ long $\times 25$ $\mathrm{cm}$ wide) set on a flat surface with a $1 \%$ slope. Each experimental plot had nine plants, and nutrient solution was delivered at $2 \mathrm{~L} \cdot \mathrm{min}^{-1}$. Every 4 weeks, nutrient solutions were replaced in the conventional treatments without recycling (NFTc). Solutions were monitored and adjusted daily for $\mathrm{pH}$ and electrical conductivity (EC). In the NFT system with recycling (NFTr) the solution was not replaced but adjusted based on $\mathrm{pH}$ and $\mathrm{EC}$ measurements. 
Table 1. Growth of greenhouse tomato cultivated for three substrates with or without nutrient solution recycling, 13 weeks after transplant.

\begin{tabular}{lccc}
\hline \hline Substrate & Recycling & $\begin{array}{c}\text { Avg dry } \\
\text { wt (kg) }\end{array}$ & $\begin{array}{c}\text { Dry } \\
\text { matter }(\%)\end{array}$ \\
\hline Rockwool & No & 2.81 & 13.30 \\
& Yes & 3.14 & 13.10 \\
NFT $^{z}$ & No & 3.01 & 13.50 \\
& Yes & 2.22 & 13.10 \\
Peatmoss & No & 3.23 & 13.60 \\
SUB & Yes & 3.70 & 14.20 \\
RE & & NS & NS \\
SUB $\times$ RE & & $*$ & NS \\
& & $* *$ & NS \\
\hline NFT $=\mathrm{nutin}$
\end{tabular}

${ }^{\mathrm{z} N F T}=$ nutrient film technique, $\mathrm{SUB}=$ substrate, and RE $=$ recycling Ns, *, ** Nonsignificant or significant at $P \geq 0.05$ and 0.01 , respectively.
In the rockwool system without recycling $(\mathrm{RWc})$, nine tomato plants were evenly placed in three 10.1 -L rockwool bags (Grodan; $15 \times 90 \times 7.5 \mathrm{~mm})$ in each of the four compartments. Nutrient solution was delivered by trickle irrigation and controlled by a lysimeter system. The average volume of drainage (over irrigation) during this experiment was fixed at $25 \%$ of the applied irrigation solution. The rockwool system with recycling (RWr) included trays placed underneath bags to collect drainage solutions weekly. At the end of each week, a mineral analysis was performed on the drainage solutions for major and trace elements. The solution then was reused after nutrient adjustments based on mineral analysis.

For the peatmoss system, 25-L bags (Allegro, Premier Peat moss) were used. Two treatments (with and without recycling; $\mathrm{PMr}$ and PMc, respectively) were applied in each of the four compartments. Irrigation was performed using electronic tensiometers (Duval, 1992) that control irrigation based on substrate matric potential (Norrie et al., 1994). Tensiometers were connected to an automatic irrigation controller (Allegro) that controlled the beginning of irrigation $(-5 \mathrm{KPa})$, the end of irrigation $(-1 \mathrm{KPa})$, automatic drainage $(25 \%$ of the applied irrigation solution), the number of irrigations (five daily), etc. Recycling of drainage solutions was performed in the same manner as for the rockwool system: drainage solutions were kept for 1 week, analyzed, and reused after nutrient adjustments based on mineral composition.

The plants received a complete nutrient solution for which EC was maintained at $2.0 \pm 0.2$ $\mathrm{dS} \cdot \mathrm{m}^{-1}$ and $\mathrm{pH}$ at $6.0 \pm 0.3$. Greenhouse temperatures were $18^{\circ} \mathrm{C}$ during the night and $21^{\circ} \mathrm{C}$ during the day. Plants were grown under natural light. During the daytime, lamps were turned on automatically only during cloudy periods for an supplemental lighting of 150 $\mu \mathrm{mol} \cdot \mathrm{m}^{-2} \cdot \mathrm{s}^{-1}$ (photosynthetic active radiation) supplied by 1000 W HPS lamps (no. 1000-SO-SHP-120-SOLUXLUMIPONIC) during a $16-\mathrm{h}$ photoperiod.

Three plants per experimental unit were removed during the 12 th week after transplanting $(9$ weeks after recycling) to measure fresh and dry weight of the leaves and stems. Mineral analyses were performed on the fifth leaf of the plants every 4 weeks after transplanting. Yield and fruit quality evaluations were

Fig. 2. Accumulation of sulfate ions in systems with nutrient solution recycling. Vertical lines indicate \pm SE of the mean. 
performed for a total of five clusters per plant.

Major and trace elements were analyzed in dried and ground leaves, as well as irrigation, drainage, and recycled solutions. The Kjeldahl method was used to analyze total $\mathrm{N}$ content in these samples. Nitrate analysis was performed using a colorimeter (TRAACS 800; Pulse Instrumentation, Saskatoon, Sask., Canada). Phosphorus, $\mathrm{K}, \mathrm{Ca}, \mathrm{Mg}, \mathrm{S}, \mathrm{Cu}, \mathrm{Fe}, \mathrm{Mn}$, $\mathrm{Zn}, \mathrm{B}$, and molybdenum were measured using an spectrophotometer (Inductively Coupled Argon Plasma 61E; Thermo Jarrell-Ash, Boston).

Statistical analysis. The experiment ended on 17 July 1993. Analyses of variance were computed for a $2 \times 3$ factorial with four replications.

When a significant $F$ test occurred, a least significant difference means operation procedure was performed.

\section{Results and Discussion}

Vegetative growth. Fresh and dry weights of aerial plant parts cultivated in the NFTr system were the lowest of all treatments (Table 1). Dry weights of tomato plants cultivated in NFTr were $25 \%$ and $35 \%$ lower, respectively, compared to the RWr and PMr systems. The dry weight of plants cultivated in NFTr was $24 \%$ lower than those in NFTc.

Nutrient solution recycling in the NFT system affected plant growth. This effect was attributed to increased $\mathrm{SO}_{4}^{2-}$ concentrations (Figs. 1 and 2) as Cerda et al. (1984) and Martinez et al. (1983) reported that tomato plants cultivated with nutrient solutions high in $\mathrm{SO}_{4}^{2-}$ ions produced thin stems and small leaves. These symptoms become more evident at advanced plant age. Results of mineral analysis of the solutions showed that there was a more significant build-up of $\mathrm{SO}_{4}^{2-}$ concentrations in the NFTr system than in either the $\mathrm{RWr}$ or PMr systems (Fig 2).

Productivity. After 3 weeks of harvest (Table 2), there was no significant difference between peatmoss or rockwool culture with or without nutrient solution recycling for several yield characteristics. However, total yields of plants grown on NFTr were reduced by $27 \%$ compared to NFTc. The NFTr system also showed reductions in yield of $25 \%$ and $28 \%$, respectively, compared to 3 weeks after initial harvest.

${ }^{\mathrm{y}} \mathrm{NFT}=$ nutrient film technique.

${ }^{\mathrm{x}} \mathrm{nm}=$ not measured.
Table 2. Greenhouse tomato yields when grown with or without nutrient solution recycling in three substrates

\begin{tabular}{|c|c|c|c|c|c|}
\hline Substrate $^{z}$ & Recycling & $\begin{array}{c}\text { Total } \\
\text { yield } \\
\text { (kg/plant) }\end{array}$ & $\begin{array}{c}\text { Marketable } \\
\text { yield } \\
\text { (kg/plant) }\end{array}$ & $\begin{array}{c}\text { Marketable } \\
\text { fruit } \\
(\%)\end{array}$ & $\begin{array}{l}\text { Avg marketable } \\
\text { fruit wt } \\
\text { (g/fruit) }\end{array}$ \\
\hline \multirow[t]{2}{*}{ Rockwool } & No & 3.44 & 3.33 & 96.81 & 141.1 \\
\hline & Yes & 3.87 & 3.81 & 98.45 & 145.3 \\
\hline \multirow[t]{2}{*}{ NFT } & No & 3.86 & 3.80 & 97.08 & 172.5 \\
\hline & Yes & 2.78 & 2.74 & 96.52 & 166.7 \\
\hline \multirow[t]{2}{*}{ Peatmoss } & No & 4.11 & 3.99 & 98.41 & 157.9 \\
\hline & Yes & 3.74 & 3.61 & 98.56 & 166.2 \\
\hline SUB & & NS & NS & NS & NS \\
\hline $\mathrm{RE}$ & & $* *$ & $* *$ & NS & NS \\
\hline $\mathrm{SUB} \times \mathrm{RE}$ & & $* *$ & $* *$ & NS & NS \\
\hline
\end{tabular}

${ }_{\mathrm{z} N F T}=$ nutrient film technique, $\mathrm{SUB}=$ substrate, $\mathrm{RE}=$ recycling.

Ns, ** Nonsignificant or significant at $P \geq 0.01$.

Table 3. Mineral composition of the fifth leaf from tomato plant apex-major elements. ${ }^{\mathrm{z}}$

\begin{tabular}{|c|c|c|c|c|c|c|c|}
\hline \multirow[b]{2}{*}{ Week } & \multirow[b]{2}{*}{ Substrates } & \multirow[b]{2}{*}{ Recycling } & \multicolumn{5}{|c|}{ Mineral composition (\%) } \\
\hline & & & $\mathrm{N}$ & $\mathrm{P}$ & $\mathrm{K}$ & $\mathrm{Ca}$ & $\mathrm{Mg}$ \\
\hline \multirow[t]{6}{*}{4} & Rockwool & No & 4.06 & 0.90 & 3.68 & 1.71 & 0.4 \\
\hline & Rockwool & Yes & 5.51 & 0.95 & 3.96 & 1.85 & 0.5 \\
\hline & Peatmoss & No & 5.03 & 0.9 & 3.91 & 1.83 & 0.59 \\
\hline & Peatmoss & Yes & 5.30 & 0.98 & 4.02 & 2.14 & 0.63 \\
\hline & $\mathrm{NFT}^{\mathrm{y}}$ & No & 3.94 & 0.82 & 3.72 & 1.60 & 0.44 \\
\hline & NFT & Yes & 3.80 & 0.87 & 3.87 & 1.70 & $\mathrm{~nm}^{\mathrm{x}}$ \\
\hline \multirow[t]{6}{*}{8} & Rockwool & No & 4.65 & 0.90 & 5.11 & 1.49 & 0.38 \\
\hline & Rockwool & Yes & 4.77 & 0.95 & 5.51 & 1.17 & 0.34 \\
\hline & Peatmoss & No & 4.47 & 0.90 & 5.53 & 1.78 & 0.36 \\
\hline & Peatmoss & Yes & 4.90 & 0.98 & 5.25 & 1.47 & 0.35 \\
\hline & NFT & No & 4.48 & 0.82 & 4.60 & 1.87 & 0.47 \\
\hline & NFT & Yes & 4.56 & 0.87 & 4.76 & 1.84 & 0.48 \\
\hline \multirow[t]{6}{*}{12} & Rockwool & No & 2.78 & 0.59 & 4.78 & 1.15 & 0.15 \\
\hline & Rockwool & Yes & 2.96 & 0.62 & 4.78 & 1.12 & 0.17 \\
\hline & Peatmoss & No & 2.97 & 0.66 & 5.00 & 1.13 & 0.18 \\
\hline & Peatmoss & Yes & 2.76 & 0.66 & 4.75 & 1.12 & 0.16 \\
\hline & NFT & No & 3.01 & 0.74 & 5.51 & 1.16 & 0.20 \\
\hline & NFT & Yes & 2.31 & 0.67 & 4.2 & 1.19 & 0.16 \\
\hline $\mathrm{WK}^{\mathrm{w}}$ & & & $* *$ & $* *$ & $* *$ & $* *$ & ** \\
\hline SUB $^{w}$ & & & $* *$ & NS & NS & NS & NS \\
\hline $\mathrm{WK} \times \mathrm{SUB}$ & & & $* *$ & $* *$ & $* *$ & $* *$ & NS \\
\hline $\mathrm{RE}^{\mathrm{w}}$ & & & NS & $*$ & NS & NS & NS \\
\hline $\mathrm{SUB} \times \mathrm{RE}$ & & & $* * *$ & NS & NS & NS & NS \\
\hline $\mathrm{WK} \times \mathrm{RE}$ & & & NS & NS & NS & NS & NS \\
\hline $\mathrm{SUB} \times \mathrm{WK} \times \mathrm{RE}$ & & & NS & NS & NS & NS & NS \\
\hline
\end{tabular}

${ }^{\mathrm{z}}$ Values represent the average of four replications.

${ }^{\mathrm{w}} \mathrm{WK}=$ week, $\mathrm{SUB}=$ substrate, and $\mathrm{RE}=$ recycling.

Ns, *,**,*** Nonsignificant or significant at $P \geq 0.05,0.01$, and 0.001 , respectively.

peatmoss and rockwool systems (PMr and RWr) with nutrient solution recycling. There were no differences in the percentage of marketable fruit or average fruit weight for tomato plants cultivated in the three substrates with or without nutrient solution recycling.

Mineral composition of foliar tissue. Leaf concentrations of total $\mathrm{NO}_{3}-\mathrm{N}, \mathrm{P}, \mathrm{K}, \mathrm{Fe}, \mathrm{Mn}, \mathrm{Zn}$, and $\mathrm{Cu}$ decreased between the fourth and 12th week after transplanting for all treatments (Tables 3 and 4). Concentrations of $\mathrm{Ca}, \mathrm{Mg}$, and $\mathrm{B}$ were stable at the beginning of the experiment (fourth and eighth weeks) but de- 
Table 4. Mineral composition of the fifth leaf from tomato plant apex-trace elements. ${ }^{\mathrm{z}}$

\begin{tabular}{|c|c|c|c|c|c|c|c|}
\hline \multirow[b]{2}{*}{ Week } & \multirow[b]{2}{*}{ Substrates } & \multirow[b]{2}{*}{ Recycling } & \multicolumn{5}{|c|}{ Mineral composition $(\%)$} \\
\hline & & & $\mathrm{N}$ & $\mathrm{P}$ & $\mathrm{K}$ & $\mathrm{Ca}$ & $\mathrm{Mg}$ \\
\hline \multirow[t]{6}{*}{$\overline{4}$} & Rockwool & No & 43.50 & 24.75 & 135.25 & 56.00 & 27.4 \\
\hline & Rockwool & Yes & 46.50 & 37.75 & 154.50 & 91.00 & 31.92 \\
\hline & Peatmoss & No & 53.25 & 36.00 & 170.75 & 134.25 & 30.42 \\
\hline & Peatmoss & Yes & 52.25 & 33.0 & 159.75 & 137.75 & 26.95 \\
\hline & $\mathrm{NFT}^{\mathrm{y}}$ & No & 48.50 & 49.75 & 124.00 & 53.25 & 33.33 \\
\hline & NFT & Yes & 35.25 & 47.25 & 92.50 & 52.55 & 23.5 \\
\hline \multirow[t]{6}{*}{8} & Rockwool & No & 45.75 & 28.25 & 126.75 & 153.25 & 19.23 \\
\hline & Rockwool & Yes & 46.75 & 26.75 & 103.45 & 164.5 & 21.80 \\
\hline & Peatmoss & No & 42.75 & 26.00 & 109.0 & 177.25 & 22.82 \\
\hline & Peatmoss & Yes & 42.25 & 27.75 & 122.25 & 178.5 & 22.08 \\
\hline & NFT & No & 56.75 & 23.75 & 113.25 & 63.75 & 25.10 \\
\hline & NFT & Yes & 49.25 & 31.50 & 114.25 & 98.5 & 22.83 \\
\hline \multirow[t]{6}{*}{12} & Rockwool & No & 12.25 & $\mathrm{~nm}^{\mathrm{x}}$ & 65.50 & 28.00 & 6.97 \\
\hline & Rockwool & Yes & 14.00 & 102.00 & 76.75 & 29.25 & 6.27 \\
\hline & Peatmoss & No & 12.50 & 90.00 & 61.75 & 28.50 & 4.25 \\
\hline & Peatmoss & Yes & 12.50 & 157.00 & 63.50 & 26.00 & 4.60 \\
\hline & NFT & No & 15.25 & 104.75 & 61.25 & 19.00 & 5.45 \\
\hline & NFT & Yes & 13.67 & 114.67 & 57.67 & 19.00 & 9.33 \\
\hline $\mathrm{WK}^{\mathrm{w}}$ & & & $* *$ & $* *$ & $* *$ & $* *$ & $* *$ \\
\hline SUB $^{\mathrm{w}}$ & & & NS & NS & $*$ & $* *$ & NS \\
\hline $\mathrm{WK} \times \mathrm{SUB}$ & & & $* * *$ & NS & $* *$ & $* *$ & NS \\
\hline $\mathrm{RE}^{\mathrm{w}}$ & & & NS & $*$ & NS & NS & NS \\
\hline $\mathrm{SUB} \times \mathrm{RE}$ & & & NS & NS & NS & NS & NS \\
\hline $\mathrm{WK} \times \mathrm{RE}$ & & & NS & $*$ & NS & NS & NS \\
\hline $\mathrm{SUB} \times \mathrm{WK} \times \mathrm{RE}$ & & & NS & NS & NS & NS & NS \\
\hline
\end{tabular}

${ }^{\mathrm{z}}$ Values represent the average of four replications.

${ }^{\mathrm{y}} \mathrm{NFT}=$ nutrient film technique.

${ }^{\mathrm{x}} \mathrm{nm}=$ not measured.

${ }^{w} \mathrm{WK}=$ week, $\mathrm{SUB}=$ substrate, $\mathrm{RE}=$ recycling.

Ns, ${ }^{*},{ }^{* *},{ }^{* * *}$ Nonsignificant or significant at $P \geq 0.05,0.01$, and 0.001 , respectively.

the absorption of major elements was not affected. Chouinard (1991) found similar differences in cucumber plants cultivated in NFT systems with different degrees of root oxygenation.

Although foliar analysis may not give a precise nutritional diagnosis, we suggest that plant nutritional needs were met in all treatments since there was no deficiency or toxicity problems. Also, over the 12-week cultivation period, mineral composition of the foliar tissues were within standards established by Adams (1984).

Nutrient uptake. Irrigation and drainage solutions were analyzed weekly to determine the quantity of individual nutrient elements needed to rebalance each solution. These analyses also indirectly indicated the quantities of each nutrient absorbed according to plant growth stage and cultivation system. However, the nature of the cultivation systems did not allow for an exact comparison between mineral compositions of each irrigation and drainage solution.

Comparisons between peatmoss and rockwool drainage solutions indicated similar daily

creased at the end of the experiment (12th week).

Our results support those obtained by Tremblay et al. (1987) and Chouinard (1991) who found reductions in leaf $\mathrm{NO}_{3}-\mathrm{N}, \mathrm{P}, \mathrm{K}$, and $\mathrm{Fe}$ in plants grown under artificial light (HPS). In addition to these studies, Charbonneau et al. (1988) reported an increase in Ca and $\mathrm{Mg}$ concentrations for plants grown under artificial lighting, corresponding to the eighth week after transplanting in our experiments. After this time, Ca and Mg levels stabilized at slightly lower concentrations. Other studies by Zhang and Wu (1989) indicated that $\mathrm{Zn}$ concentration in tomato leaves increases under an increased natural PPF. Zinc may interfere with chlorophyll synthesis and the activity of several enzymes. A higher plant metabolism, caused by an increase in PPF, may increase $\mathrm{Zn}$ demand and, thus, its concentration in the leaves.

Nutrient solution recycling had a significant effect on the mineral composition of vegetative tissue during the three foliar sampling periods (fourth, eighth, and 12th weeks) (Tables 3 and 4). Continuous use of the same nutrient solutions (NFTr) caused a significant decrease in total $\mathrm{NO}_{3}-\mathrm{N}$ in the fifth leaf compared to the NFTc system and the rockwool and peatmoss systems with and without nutrient solution recycling. Leaf $\mathrm{N}$ concentration of plants in the NFTr system was the lowest of all treatments 12 weeks after transplanting, but there were no differences between the other treatments (Table 3) and no differences in foliar $\mathrm{NO}_{3}-\mathrm{N}$ in any treatments 4 and 8 weeks after transplanting.

Leaf $\mathrm{Mg}$ concentration was higher in peatmoss (PMr and PMc) and rockwool (RWr and RWc) than in NFT (NFTr and NFTc). This result cannot be attributed to fluctuations in root oxygenation since irrigation dynamics. Plants had high absorption rates for $\mathrm{N}, \mathrm{P}, \mathrm{Ca}$, and $\mathrm{Mg}$ and low absorption of $\mathrm{K}$ during the early stages of plant development (Tables 5). Once fruit growth started, plant nutrient requirements changed. Leaf production is slowed down, leading to a reduction in $\mathrm{N}$ and $\mathrm{Ca}$ requirements, which, in turn, are related to the rate of plant growth and transpiration.

Fruit development requires increased K. Potassium : N and K : Ca ratios were maintained at 2 in the fertigation solution, commencing the fourth week after transplantation onward. However, given that mineral absorption is active and selective, the transpiration rate exerts an appreciable influence on mineral requirements (Salisbury and Ross, 1985), especially with regard to $\mathrm{Ca}$ and $\mathrm{Mg}$ (Armstrong and Kirby, 1979; Clarkson and Hanson, 1980). Later in our study, a decrease in the vegetative growth rate and leaf size induced a reduction in $\mathrm{Ca}$ and $\mathrm{Mg}$ absorption. Leaf mineral analysis indicated that $\mathrm{Ca}$ and $\mathrm{Mg}$ leaf concentrations decrease with plant development; therefore, drainage solution amendments should be lower in $\mathrm{N}, \mathrm{Ca}$, and $\mathrm{Mg}$ and higher in $\mathrm{K}$ as the plant develops.

Trace element concentrations in rockwool and peatmoss drainage solutions varied slightly. Demand for trace elements does not change much with plant development, except for $\mathrm{Mn}$ and $\mathrm{Zn}$, which follow the same trends as the major elements (Chouinard, 1991). Absorption of other trace elements ( $\mathrm{Fe}, \mathrm{Cu}$, and $\mathrm{B}$ ) were relatively stable throughout the experiment. Foliar analysis indicated that plants cultivated in the NFT systems absorbed less Mn than those grown in rockwool and peatmoss systems (Table 4). These results may be explained by poor root oxygenation 
(Chouinard, 1991; Schwarz, 1989; Veen, 1981). Of plants grown in the NFTr system, low leaf concentrations of certain elements $\left(\mathrm{NO}_{3}-\mathrm{N}, \mathrm{K}\right.$, and $\mathrm{Mn}$ ) compared to other systems indicate that not only does root oxygenation significantly affect uptake but that mineral balances in the recirculating solutions also affect mineral absorption. Continuous nutrient solution amendments (recycling) to the NFT system were not enough to maintain a well-balanced solution with adequate mineral concentrations (Cooper, 1979). The number and frequency of $\mathrm{pH}$ and $\mathrm{EC}$ adjustments for NFT solutions do not take into consideration the absorption of specific mineral elements in the recirculating solution. In fact, the various relationships between mineral elements that ensure proper nutrition can be modified, and interactions between several different mineral elements can take place.

Adjustments to peatmoss and rockwool drainage solutions and the recirculating irrigation solution for the NFT system allowed us to follow the evolution of vari-

ous mineral elements and their relationships in the irrigation solutions. For each one of the treatments with nutrient solution recycling ( $\mathrm{RWr}, \mathrm{PMr}$, and NFTr), nutrient analyses indicated that $\mathrm{K}: \mathrm{N}, \mathrm{K}: \mathrm{Mg}$, and $\mathrm{K}$ : Ca ratios in PMr and RWr irrigation solutions were within standards values ( 1.5 to $2.5,5$ to 7 , and 2 to 2.25 , respectively) throughout the cultivation period. Since leaf mineral analysis indicated no differences in $\mathrm{Ca}$ concentration between treatments, we concluded that $\mathrm{K}$ ions interacted with certain elements in mineral absorption in the NFTr treatment, which was adjusted for $\mathrm{pH}$ and $\mathrm{EC}$ only.

Monitoring the $\mathrm{SO}_{4}^{2-}: \mathrm{K}$ ratio (Fig. 1) indicated differences among the three nutrient solutions. This ratio varied between 0.82 to 1.66 and 0.75 to 1.68 for the rockwool and peatmoss substrates, respectively. In the NFTr system, this ratio was initially 1.57 and reached 4.92 by the end of the experiment. According to Marschner (1983), this progressive accumulation of sulfates in recirculating solutions could reduce $\mathrm{K}$ absorption by plants in NFTr systems. Although cation absorption rate is not affected by anion concentration, Marschner (1986) indicated that at high concentrations, ions with a low absorption rate $\left(\mathrm{SO}_{4}^{2-}\right.$ and $\left.\mathrm{Ca}\right)$ considerably reduced absorption rates of $\mathrm{K}$ and chlorides.

The absorption of cations and anions also requires a compensation of ion electric charges (cations and anions) in root cells.
Therefore, in nutrient solutions with high $\mathrm{SO}_{4}^{2-}$ concentrations, adjustment of the electric charge in the root cell becomes a limiting factor in $\mathrm{K}$ and $\mathrm{Cl}$ absorption when accompanied (cotransport) by $\mathrm{SO}_{4}^{2-}$ and $\mathrm{Ca}$, respectively. Foliar analyses indicated that in the NFTr system, $\mathrm{N}-\mathrm{NO}_{3}$ were absorbed in lower quantities than in the other systems with nutrient solution recycling. In fact, continuous use of the same recirculating nutrient solution in NFT systems leads to an $\mathrm{Cl}$ accumulation, which, in turn, may interfere with $\mathrm{N}$ $\mathrm{NO}_{3}$ absorption. Leaf $\mathrm{NO}_{3}$ concentration was significantly lower in the NFTr system compared to other systems.

Ion accumulation during recycling. During recycling trials, certain elements have a tendency to accumulate in the recycled solutions. Initial $\mathrm{SO}_{4}^{2-}$ concentrations in the irrigation solutions were $200 \mathrm{mg} \cdot \mathrm{L}^{-1}$ for all three cultivation systems but increased after 8 weeks of recycling (Fig. 2). Rockwool and peatmoss systems with recycling indicated $\mathrm{SO}_{4}^{2-}$ concentrations $260 \%$ and

Table 5. Major elements: mineral composition of fertigation solutions and relative proportions of drainage and concentrated solutions for tomatoes grown in rockwool and peat moss (milligrams per liter).

\begin{tabular}{|c|c|c|c|c|c|c|}
\hline \multirow[b]{2}{*}{ Week } & \multirow[b]{2}{*}{ Solution } & \multicolumn{5}{|c|}{ Mineral composition $(\%)$} \\
\hline & & $\mathrm{NO}_{3}-\mathrm{N}$ & $P$ & $\mathrm{~K}$ & $\mathrm{Ca}$ & $\mathrm{Mg}$ \\
\hline \multirow[t]{5}{*}{$\overline{1}$} & Fertigation & 170.0 & 50.0 & 275.0 & 140.0 & 45.0 \\
\hline & Drainage-rockwool & 30.2 & 11.3 & 67.5 & 35.6 & 8.5 \\
\hline & Drainage_-peatmoss & 12.0 & 11.9 & 77.3 & 21.1 & 10.4 \\
\hline & Additions-rockwook & 139.8 & 38.7 & 207.5 & 04.4 & 36.5 \\
\hline & Additions—peatmoss & 158.0 & 38.1 & 197.7 & 118.9 & 34.6 \\
\hline \multirow[t]{5}{*}{2} & Fertigation & 184.0 & 50.0 & 275.0 & 140.0 & 45.0 \\
\hline & Drainage—rockwool & 38.7 & 10.2 & 69.0 & 42.3 & 9.6 \\
\hline & Drainage-peatmoss & 34.6 & 16.7 & 84.5 & 39.2 & 16.5 \\
\hline & Additions-rockwool & 145.3 & 39.8 & 206.0 & 97.7 & 35.4 \\
\hline & Additions-peatmoss & 149.4 & 33.3 & 190.5 & 100.8 & 28.5 \\
\hline \multirow[t]{5}{*}{3} & Fertigation & 184.0 & 50.0 & 275.0 & 140.0 & 45.0 \\
\hline & Drainage—rockwool & 36.8 & 12.0 & 66.4 & 39.4 & 8.5 \\
\hline & Drainage-peatmoss & 64.0 & 17.9 & 119.9 & 63.2 & 22.0 \\
\hline & Additions-rockwool & 147.2 & 38.0 & 208.6 & 100.6 & 36.5 \\
\hline & Additions-peatmoss & 20.0 & 32.1 & 55.1 & 76.8 & 23.0 \\
\hline \multirow[t]{5}{*}{4} & Fertigation & 184.0 & 50.0 & 275.0 & 140.0 & 45.0 \\
\hline & Drainage—rockwool & 74.1 & 20.7 & 102.8 & 102.0 & 20.4 \\
\hline & Drainage_peatmoss & 84.6 & 21.5 & 121.6 & 97.0 & 27.9 \\
\hline & Additions-rockwool & 109.9 & 29.3 & 172.2 & 38.0 & 24.6 \\
\hline & Additions-peat moss & 99.4 & 28.5 & 153.4 & 43.0 & 17.1 \\
\hline \multirow[t]{5}{*}{5} & Fertigation & 170.0 & 50.0 & 328.0 & 140.0 & 45.0 \\
\hline & Drainage_rockwool & 80.2 & 20.4 & 109.1 & 95.9 & 22.8 \\
\hline & Drainage_-peatmoss & 68.7 & 21.4 & 108.6 & 87.2 & 26.7 \\
\hline & Additions-rockwool & 89.8 & 29.6 & 218.9 & 44.1 & 22.2 \\
\hline & Additions—peatmoss & 101.3 & 28.6 & 219.4 & 52.8 & 18.3 \\
\hline \multirow[t]{5}{*}{6} & Fertigation & 170.0 & 50.0 & 328.0 & 140.0 & 45.0 \\
\hline & Drainage-rockwool & 63.7 & 13.7 & 81.0 & 71.9 & 19.1 \\
\hline & Drainage_-peatmoss & 63.2 & 19.4 & 101.8 & 82.9 & 26.9 \\
\hline & Additions-rockmoss & 106.3 & 36.3 & 247.0 & 68.1 & 25.9 \\
\hline & Additions-peatmoss & 106.8 & 30.6 & 226.2 & 57.1 & 18.1 \\
\hline \multirow[t]{5}{*}{7} & Fertigation & 170.0 & 50.0 & 28.0 & 140.0 & 45.0 \\
\hline & Drainage-rockwool & 81.0 & 16.1 & 114.9 & 105.3 & 33.3 \\
\hline & Drainage_-peatmoss & 54.3 & 13.1 & 90.2 & 71.9 & 22.5 \\
\hline & Additions-rockwool & 89.0 & 33.9 & 213.1 & 34.7 & 11.7 \\
\hline & Additions_-peatmoss & 115.7 & 36.9 & 237.8 & 68.1 & 22.5 \\
\hline \multirow[t]{5}{*}{8} & Fertigation & 170.0 & 50.0 & 328.0 & 140.0 & 45.0 \\
\hline & Drainage-rockwool & 76.2 & 15.7 & 89.1 & 97.7 & 22.1 \\
\hline & Drainage_-peatmoss & 67.0 & 14.5 & 84.6 & 78.1 & 26.7 \\
\hline & Additions-rockwool & 93.8 & 34.3 & 238.9 & 42.4 & 22.9 \\
\hline & Additions-peatmoss & 103.0 & 35.5 & 243.4 & 61.9 & 18.3 \\
\hline
\end{tabular}


Table 6. Trace elements: mineral composition of fertigation solutions and relative proportions of drainage and concentrated solutions of tomatoes grown in rockwool and peatmoss (milligrams per liter).

\begin{tabular}{|c|c|c|c|c|c|c|}
\hline $\begin{array}{l}\text { Weeks after } \\
\text { planting }\end{array}$ & Solution & $\mathrm{Cu}$ & $\mathrm{Fe}$ & $\mathrm{Mn}$ & $\mathrm{Zn}$ & $\mathrm{B}$ \\
\hline \multirow[t]{5}{*}{1} & Fertigation & 0,1 & 4,0 & 1,0 & 0,5 & 0,3 \\
\hline & Drainage-rockwool & 0,1 & 0,9 & 0,2 & 0,2 & 0,1 \\
\hline & Drainage_-peatmoss & 0,0 & 1,0 & 0,1 & 0,4 & 0,1 \\
\hline & Additions-rockwool & 0,0 & 3,1 & 0,8 & 0,3 & 0,2 \\
\hline & Additions-peatmoss & 0,1 & 3,0 & 0,9 & 0,1 & 0,2 \\
\hline \multirow[t]{5}{*}{2} & Fertigation & 0,1 & 4,0 & 1,0 & 0,5 & 0,3 \\
\hline & Drainage-rockwool & 0,1 & 1,1 & 0,2 & 0,2 & 0,1 \\
\hline & Drainage_-peatmoss & 0,1 & 1,1 & 0,2 & 0,4 & 0,1 \\
\hline & Additions-rockwool & 0,0 & 2,9 & 0,8 & 0,3 & 0,2 \\
\hline & Additions-peatmoss & 0,0 & 2,9 & 0,8 & 0,1 & 0,2 \\
\hline \multirow[t]{5}{*}{3} & Fertigation & 0,1 & 4,0 & 1,0 & 0,5 & 0,3 \\
\hline & Drainage-rockwool & 0,0 & 1,0 & 0,2 & 0,2 & 0,1 \\
\hline & Drainage-peatmoss & 0,1 & 1,1 & 0,2 & 0,3 & 0,1 \\
\hline & Additions-rockwool & 0,1 & 3,0 & 0,8 & 0,3 & 0,2 \\
\hline & Additions-peatmoss & 0,0 & 2,9 & 0,8 & 0,2 & 0,2 \\
\hline \multirow[t]{5}{*}{4} & Fertigation & 0,1 & 4,0 & 1,0 & 0,5 & 0,3 \\
\hline & Drainage-rockwool & 0,1 & 1,6 & 0,5 & 0,3 & 0,2 \\
\hline & Drainage_-peatmoss & 0,1 & 1,2 & 0,2 & 0,4 & 0,2 \\
\hline & Additions-rockwool & 0,0 & 2,4 & 0,5 & 0,2 & 0,1 \\
\hline & Additions-peatmoss & 0,0 & 2,8 & 0,8 & 0,1 & 0,1 \\
\hline \multirow[t]{5}{*}{5} & Fertigation & 0,1 & 4,0 & 1,0 & 0,5 & 0,3 \\
\hline & Drainage-rockwool & 0,1 & 1,9 & 0,4 & 0,4 & 0,2 \\
\hline & Drainage-peatmoss & 0,1 & 1,4 & 0,2 & 0,3 & 0,2 \\
\hline & Additions-rockwool & 0,0 & 2,1 & 0,6 & 0,1 & 0,1 \\
\hline & Additions-peatmoss & 0,0 & 2,6 & 0,8 & 0,2 & 0,1 \\
\hline \multirow[t]{5}{*}{6} & Fertigation & 0,1 & 4,0 & 1,0 & 0,5 & 0,3 \\
\hline & Drainage-rockwool & 0,1 & 1,6 & 0,3 & 0,3 & 0,2 \\
\hline & Drainage_peatmoss & 0,1 & 1,2 & 0,1 & 0,3 & 0,2 \\
\hline & Additions-rockwool & 0,0 & 2,4 & 0,7 & 0,2 & 0,1 \\
\hline & Additions—peatmoss & 0,0 & 2,8 & 0,9 & 0,2 & 0,1 \\
\hline \multirow[t]{5}{*}{7} & Fertigation & 0,1 & 4,0 & 1,0 & 0,5 & 0,3 \\
\hline & Drainage-rockwool & 0,1 & 1,8 & 0,4 & 0,5 & 0,2 \\
\hline & Drainage_peatmoss & 0,0 & 0,6 & 0,1 & 0,2 & 0,1 \\
\hline & Additions-rockwool & 0,0 & 2,2 & 0,6 & 0,0 & 0,1 \\
\hline & Additions-peatmoss & 0,1 & 3,4 & 0,9 & 0,3 & 0,2 \\
\hline \multirow[t]{5}{*}{8} & Fertigation & 0,1 & 4,0 & 1,0 & 0,5 & 0,3 \\
\hline & Drainage-rockwool & 0,1 & 1,7 & 0,4 & 0,4 & 0,2 \\
\hline & Drainage_peatmoss & 0,0 & 1,2 & 0,1 & 0,3 & 0,2 \\
\hline & Additions-rockwool & 0,0 & 2,3 & 0,6 & 0,1 & 0,1 \\
\hline & Additions_-peatmoss & 0,1 & 2,8 & 0,9 & 0,2 & 0,1 \\
\hline
\end{tabular}

\section{Conclusion}

Hydroponic greenhouse tomato growth and productivity are considerably affected by prolonged recycling of nutrient solutions if adjustments are based solely on $\mathrm{pH}$ and EC measurements. Our results indicate that plant dry weight and total yields of the tomato plants were reduced in the NFTr system. While maintaining EC and $\mathrm{pH}$ at optimum levels, no nutritional problems were observed in plants cultivated in the NFTc system. However, unbalanced mineral concentrations resulted in the NFTr system from $\mathrm{SO}_{4}^{2-}$ accumulation due to recycling, occurring over long periods of nutrient solution use. Ion interaction affected the absorption of certain mineral elements $(\mathrm{K})$, and consequently, fruit weight and yields were reduced. We can conclude that hydroponic nutrient solution recycling does not appear to be compatible with the NFT cultivation system if adjustment is based only on pH and EC. Further studies should be performed to adapt nutrient solution recycling to the NFT system. Buildup of $\mathrm{SO}_{4}^{2-}$ as well as other ion concentrations $(\mathrm{Cl}$ and $\mathrm{Na})$ also may occur in the rockwool and peatmoss systems if solution recycling is used over a long cultivation period.

\section{Literature Cited}

Adams, P. 1984. Nutritional disorders of cucumbers. Acta Hort. 156:251-256.

Armstrong, M.J. and E.A. Kirby. $210 \%$ higher, respectively, than ones measured on the fourth week of cultivation (first week of recycling). The NFTr had $360 \%$ more $\mathrm{SO}_{4}^{2-}$ than the original solution. Each week, $100 \mathrm{~L}$ of nutrient solution were applied in the rockwool and peatmoss systems (2 L/ plant per day) while a level of only $20 \mathrm{~L}$ was constantly maintained in the NFT system. The NFT nutrient solution was adjusted daily based on EC and $\mathrm{pH}$ in the NFT system. In the rockwool and peatmoss systems, the larger volume of nutrient solution resulted in a per-unit-volume mineral absorption that was less than that for the NFT system. An accumulation of $\mathrm{SO}_{4}^{2-}$ in the irrigation solution for the NFT system, due to increased $\mathrm{K}$ and $\mathrm{Mg}$ absorption rates, will continue over time as the solution is recycled.

The $\mathrm{SO}_{4}^{2-}$ accumulation increased less rapidly in the peat and rockwool systems, partly because the dilution factors were higher. It can be hypothesized that prolonged recycling in the substrate systems also would result eventually in the build-up of critical $\mathrm{SO}_{4}^{2-}$ concentrations.
1979. The influence of humidity on the mineral composition of tomato plants with special reference to Ca distribution. Plant and Soil 52:427435.

Baars, B. 1992. Water works. Grower. May:15-16.

Boivin, C. 1990. La recirculation de la solution nutritive en culture sur laine de roche, p. 76-80. In: Cahier des conférences. 9e Journée d'information sur les Cultures Abritées, Université Laval, Quebec, Canada.

Cerda, A., F.G. Martinez, M. Caro, and F.G. Fernandez. 1984. Effect of sulfur deficiency and excess on yield and sulfur accumulation in tomato plants. J. Plant. Nutr. 7(11):1529-1543.

Charbonneau, J. 1988. Influence de la conductivité électrique de la solution nutritive sur la croissance, le développement et la productivité de la tomate de serre cultivée avec ou sans éclairage d'appoint. Can. J. Plant. Sci. 68:267-276.

Chouinard,P. 1991. Croissance, oxygénation racinaire et nutrition minérale du concombre de serre cultivé en hydroponie sous éclairage d'appoint (HPS). MS Thesis. Université Laval, Québec, Canada. 
Clarkson, D.T. and J.B. Hanson. 1980. The mineral nutrition of higher plants. Annu. Rev. Plant Physiol. 31:239-298.

Conseil des Productions Végétales du Québec. 1990. Légumes de serre. Culture sur film nutritif (NFT), sur laine de roche et en milieu tourbeux. Conseil des Productions Végétales du Québec, Québec, Canada.

Cooper, A. 1979. The ABC of NFT. Grower Books, London.

De Hoog, J. 1990. New developments in substrate culture. Can. Greenhouse Conf., Guelph Univ., Ontario, Canada, 2-8 Sept.

Duval, A. 1992. Influence de la tension matricielle sur la poductivité et les échanges gazeux de la tomate de serre cultivée sur substrat tourbeux. MS thesis. Université Laval, Québec.

Mankin, K.R. and R. Fynn. 1992. Development of an individual nutrient uptake model. Intl. Mtg. Amer. Soc. Agr. Eng., Charlotte, N.C., 21-24 June 1992.

Marschner, H. 1983. General introduction to the mineral nutrition of plants, p. 5-63. In: A. Lauchli and R.L. Bielski (eds.). Encyclopedia of plant physiology. vol. 15A. Springer-Verlag, Berlin and New York.

Marschner, H. 1986. Mineral nutrition of higher plants. Academic, San Diego.
Martinez, V., A. Cerda, M. Caro, and F.G. Fernandez. 1983. Desarrollo y composition mineral de las plantas de tomate (Lycopersicon esculentum) en relacion con la concentration de $\mathrm{SO}_{4}$ en el medio de raices. Anales de Edafologia y Agrobiologia. 42 (7/8):1255-1268.

Norrie, J., M.E.D. Graham, and A. Gosselin. 1994. Potential evapotranspiration as a means of predicting irrigation timing in greenhouse tomatoes grown in peat bags. J. Amer. Soc. Hort. Sci. 119:163-168.

Salisbury, F.B. and C.W. Ross. 1985. Plant physiology. 3rded. Wadsworth Publishing Co., Belmont, Calif.

Schwarz, M. 1989. Oxygenating of nutrient solution in normal and stress conditions. Soilless Culture 5:45-53.

Tremblay, N., M. J. Trudel, and A. Gosselin. 1987. Influence of irradiance photoperiod combination on tomato mineral nutrition. Can. J. Plant Sci. 67:559-566.

Veen, B.W. 1981. Relation between root respiration and root activity. Plant and Soil 63:73-76.

Zhang, G. and Z. Wu. 1989. Relationship between light intensity and requirement for zinc in tomato plants. J. Plant Nutr. 12:633-646. 